\title{
In the Shadow of Great Powers: A Comparative Study of Various Approaches to Regionalism in Central Asia
}

\author{
Xu Zhengyuan *
}

\section{Introduction}

Alongside the rapid development of globalization, the post-Cold War era has witnessed the expansion of various forms of regional cooperation in many areas of the world. Regionalism, therefore - both in reference to the construction of a regional identity ("soft regionalism") and the building of regional cooperative institutions ("hard regionalism") ${ }^{1}$ - has become a salient ongoing process worldwide, involving the participation of both states and non-state actors as a response to globalization. Different from the "old regionalism" that arose immediately after World War II, which underscored the economic and security dimensions of regional integration and the dominant role of external power or even hegemony in it, the "new regionalism" that is increasingly widespread nowadays emphasizes spontaneous regional cooperation in a variety of areas, including politics, economy, security, culture, etc. ${ }^{2}$

For Central Asia (a region consisting of Kazakhstan, Kyrgyzstan, Tajikistan, Uzbekistan, and Turkmenistan), however, the "new regionalism" wave has not yet arrived. Instead, a pattern of great power-sponsored regionalism has dominated the development of structures of regional cooperation. Although the dissolution of the USSR and the following independence of the five Central Asian states once generated opportunities to form self-sustaining regional cooperation frameworks based on common interests that could lead to a functioning regionalism, the disagreements among the states caused by water resource disputes, border issues, and other conflicts of interest impeded them from making substantial moves. ${ }^{3}$ In addition, since the newly independent states in Central Asia are quite concerned with their hard-won sovereignty and are still hampered by their relatively poor economic performance, the political will and national capabilities to promote usually binding regional cooperation projects are inevitably inadequate. ${ }^{4} \mathrm{~A}$ good instance of such challenges is the failure of the Central Asian Cooperation Organization (CACO), a spontaneously initiated regional project consisting of all the five Central Asian states.

* $\mathrm{Xu}$ Zhengyuan is a Senior Lecturer in the Faculty of School of International Studies at Renmin University on China.

1 Louise Fawcett, "Exploring Regional Domains: A Comparative History of Regionalism," International Affairs 80:3 (2004): 433.

2 Bjorn Hettne and Fredrik Soderbaum, "The New Regionalism Approach," available at www.unisa.ac.za/Default.asp?Cmd=ViewContent\&ContentID $=11583 \& P$ _XSLFile $=$ unisa/ accessibility.xsl.

3 Annette Bohr, "Regionalism in Central Asia: New Geopolitics, Old Regional Order," International Affairs 80:3 (2004): 485.

4 Fawcett, "Exploring Regional Domains: A Comparative History of Regionalism," 443-44. 
The new geopolitical realities in Central Asia after the Cold War (and especially after the terrorist attacks of 11 September 2001) invited external great powers to step in. The collapse of the former Soviet Union did not necessarily mean the end of any kind of hegemonic dominance in the region. On the contrary, the USSR's largest successor state, Russia, has been exerting overwhelming influence in its southern backyard since the early 1990s, largely driven by strategic concerns. The rich oil and gas resources in the region have also attracted attention from Europe, the U.S. and China. After 11 September 2001, "the relocation of Central Asia from the periphery to the center of the United States' zone of strategic interest" due to its adjacency to Afghanistan further reinforced the inevitability of the great powers' involvement and complicated the geopolitical situation in the region. ${ }^{5}$ The major global powers have been engaged in building various regional structures on their own designs based on their own agendas. The U.S. is focusing on building increased connections between Central and South Asia; the EU has recently established a new partnership with Central Asia; China is still preoccupied with the institutionalization of the Shanghai Cooperation Organization (SCO); while Russia is simultaneously working on bolstering the Collective Security Treaty Organization (CSTO), the Eurasian Economic Community (EURASEC), and the SCO altogether. What interests are the great powers seeking by adopting these approaches? What policy instruments do great powers use in pursuit of these goals? What effects do these approaches produce? And finally, what is the feasible design of regionalism in Central Asia? This essay will address the above questions from a comparative perspective.

\section{Theoretical Framework: Great Powers and Regionalism}

International relations theories provide us with a variety of analytical tools to examine the relations between great powers and regionalism. Neorealism, liberalism, and constructivism all demonstrate their explanatory power in this regard through their key theoretical elements such as power distribution, interdependence, and identity construction. However, as mentioned above, due to the existence of interstate disputes, the lack of regional identity, and the pervasive influence of external great powers in Central Asia, any attempts to employ liberalism and constructivism as research approaches would be doomed. This article, therefore, draws on neorealist arguments regarding great powers and regionalism as its theoretical framework.

According to the neorealist approach, the distribution of power in the international system determines states' behavior. Hegemonic or dominant power could serve as a driver for international cooperation. Weaker states would pursue cooperation when they are faced with a common threat posed by such a dominant power. They would

5 Bohr, "Regionalism in Central Asia: New Geopolitics, Old Regional Order," 485. 
also try to counterbalance or "bandwagon" the dominant power by joining multilateral regimes. ${ }^{6}$

In a given regional context, the roles that local or external great powers play in developing regionalism can be multiple. Depending on their overall interests in and specific approaches toward the region, great powers could either facilitate the building of regional structures, impede them from strengthening, or prevent their formation altogether.

Great powers' involvement in a given region could promote regionalism there. Especially when a great power has strong or even dominant influence in the region, it may seek to institutionalize its influence as an effective way to protect its strategic, economic, or political interests. ${ }^{7}$ This process could not only facilitate the building of regional structures there, but might also help foster the construction of regional identity. This in turn could enhance the external power's legitimacy and decrease its costs of dominance, ${ }^{8}$ since regional states could benefit from closer economic or security ties with the larger power and show more willingness to collaborate with them. ${ }^{9}$ In addition, regional institutions could also serve as foreign policy tools that great powers could use to realize their interests within or out of the region. ${ }^{10}$ Thus it has been hardly rare in modern history that great powers initially promote the development of regionalism in a certain region - e.g., the EU or NAFTA.

But local or external great powers may also hinder the development of regionalism in a given region. That is not only because external great powers' interventions into regional affairs and their dominance of regional structure building could undermine the capabilities and opportunities of local states to sponsor their own independent regionalism, ${ }^{11}$ but also because great powers usually follow their own interests and agendas when designing approaches toward regional cooperation in areas of interest. ${ }^{12}$ When bilateral rather than regional approaches are better suited to promote their short-term interests in the region, external powers could soften their support for efforts to build

6 Timothy McKeown, "Hegemonic Stability Theory and Nineteenth-Century Tariff Levels in Europe," International Organization 37:1 (1983): 73-91. Bandwagoning is a term used in realist discussions of international relations to refer to the act of weaker states joining a stronger power or coalition within balance of power politics, when the weaker states decide that the costs of opposing the stronger state outweigh the benefits, or when there is little chance of forming a balancing coalition.

7 S. Neil Macfarlane, "The United States and Regionalism in Central Asia," International Affairs 80:3 (2004): 447.

8 Ibid., 448.

9 Dennis Rumley, "The Geopolitics of Asia-Pacific Regionalism in the $21^{\text {st }}$ Century," The Otemon Journal of Australian Studies 31 (2005): 9.

10 James H. Mittelman and Richard Falk, "Hegemony: The Relevance of Regionalism?" in $\mathrm{Na}$ tional Perspectives on New Regionalism in the North, eds. Bjorn Hettne, Andras Inotai, and Osvaldo Sunkel (London: Macmillan, 1999), 175.

11 Bohr, "Regionalism in Central Asia: New Geopolitics, Old Regional Order," 485.

12 Macfarlane, "The United States and Regionalism in Central Asia," 447. 
regional structures. ${ }^{13}$ Even if great powers adopt regional approaches, their institutionalization efforts may reflect their own interests and preferences, which might contradict those of local states. Besides, if necessary, the external powers would always have the capabilities to turn their backs on their commitments to regional institutions, especially those of a binding variety.

From the perspective of regional states, the pattern of their interactions with great powers is also an important factor affecting the development of regionalism. As neorealists argue, when an external power's involvement in regional affairs is regarded as a threat by the local states in a region, the latter will usually choose to balance the great power by cooperating with each other in a variety of realms. In this sense, an external power could serve as a driver of closer regional cooperation by presenting a perceived threat. ${ }^{14}$ If there is no such perceived threat, however, local states may adopt a strategy of "bandwagoning" toward the external great power, because under these circumstances the external power could be viewed by a local state as a provider of security or economic benefits, or even a strategic tool that can be used to balance against neighboring states. ${ }^{15}$

Finally, the development of regionalism could be seriously impeded and further complicated when local states are involved in a variety of regional arrangements with different or competing missions and sponsored by more than one external great power, since these powers will quite often be pursuing different or even conflicting interests. Local states have to choose according to their respective interests which great power to balance or align with, and what regional institutions to join or reject. Thus, competition between different regional structures and great powers would undermine local states' common will and efforts in promoting regionalism based on common interests and values. ${ }^{16}$ Furthermore, "states with overlapping regional membership may place themselves in cross-pressured situations which can adversely affect the internal coherence of regional groups due to goal conflicts." 17

In sum, the roles that local or external great powers could play in the development of regionalism would depend on their interests and approaches in a certain region, the patterns of local states' behaviors, and the relationship between different regional structures sponsored by the great powers. How these factors interact should be illuminated when we examine the progress of regionalism in Central Asia, where great powers like the European Union, the United States, Russia, and China all play a role.

13 Ibid., 448.

14 Ibid., 447.

15 Ibid., 458.

16 Roy Allison, "Regionalism, Regional Structures and Security Management in Central Asia," International Affairs 80:3 (2004), p. 464.

17 Dennis Rumley, "The Geopolitics of Asia-Pacific Regionalism in the $21^{\text {st }}$ Century," 9. 
FALL 2010

\section{The EU, the U.S., Russia, and China: Various Approaches to Regionalism in Central Asia}

As several scholars have recently noted, "The interest and action of all the great powers of the international system come together in Central Asia." ${ }^{18}$ The EU, the U.S., Russia, and China - the four most prominent external powers playing a role in the region-have adopted different approaches to regionalism in Central Asia. This section will explore those approaches based on an analysis of these four powers' interests, policy instruments, and the ensuing effects.

\section{The U.S. Approach: A Connected Central and South Asia}

The two decades since the dissolution of the USSR have seen a rapid evolution of U.S. interests and polices toward Central Asia. Before 2001, the U.S. was mostly concerned with the issue of nonproliferation of nuclear weapons and its access to the region's energy resources, endorsing Russia's special status there. After 2001, with the initiation of the war in Afghanistan and the increasingly proactive involvement of other regional powers (namely Russia, China, and Iran), the U.S. redefined its interests toward Central Asia. Strategically, Central Asia is not only "an important theater in the war on terrorism," but also "a theater where America might counter a revived Russia or China" as well as "a place to blunt any extension of Iranian influence." ${ }^{19}$ Following 11 September 2001, the need to check and diminish the radical Islamist influence in the region was also high on the U.S. strategic agenda. ${ }^{20}$ Economically, it is in the United States' interest to maintain equal access to the rich sources of energy in the region, diversify its export routes, and prevent Russia and China from controlling the resources there. ${ }^{21}$ In addition to these economic priorities, building democracies, promoting economic reforms, and improving the protection of human rights are also long-term goals that the U.S. is pursuing in this region.

To realize these interests (and particularly to facilitate the war in Afghanistan), the U.S. has prioritized bilateral approaches - such as establishing a strategic partnership with Uzbekistan, as well as providing economic and military assistance to local states - while its efforts toward regional cooperation have been "few and not notably effective." 22 As an adjustment, the U.S. employed trans-regional means aimed at pull-

18 Mario Esteban and Nicolas de Pedro, eds., Great Powers and Regional Integration in Central Asia: A Local Perspective (Madrid: Exlibris Ediciones S.L., 2009), 7; available at www.falternativas.org/la-fundacion/documentos/libros-e-informes/great-powers-and-regionalintegration-in-central-asia-a-local-perspective.

19 Stephen Blank, “The Strategic Importance of Central Asia,” Parameters (Spring 2008): 73.

20 Svante E. Cornell, "The United States and Central Asia: in the Steppes to Stay?" Cambridge Review of International Affairs 17:2 (July 2004): 242.

21 Stephen Blank, "U.S. Interests in Central Asia and the Challenges to Them," 3; available at www.strategicstudiesinsitutute.army.mil.

22 S. Frederick Starr, “A 'Greater Central Asia Partnership' for Afghanistan and its Neighbors," Silk Road Paper, Central Asia-Caucasus Institute, Silk Road Studies Program (March 2005), 11; available at www.stimson.org/newcentury/pdf/Strategy.pdf. 
ing the Central Asian states into a larger regional framework where it has a strong influence.

First, the U.S. has been trying to promote NATO's Partnership for Peace (PfP) program to increase the ties between NATO and the Central Asian countries, in order to exert a higher level of control in the region and facilitate the war effort in Afghanistan. Second, it created a trans-regional approach to Central and South Asia in 2005. ${ }^{23}$

Sharing in common some basic conception with the "Greater Central Asia Partnership" project, this new approach incorporated Central and South Asia into a large regional framework with Afghanistan as the nexus, ${ }^{24}$ based on the premise that "Afghanistan, at the center of this region, can be a bridge that links South and Central Asia." 25 Accordingly, the Bureau of South and Central Asian Affairs became the agency in charge of relations with the region, replacing the Bureau of South Asian Affairs. The rationale behind this regional arrangement lies in the U.S.'s important role in South Asia: "Our relations with the nations of South Asia can serve as a foundation for deeper engagement throughout Central Asia." ${ }^{26}$ Apparently India's closer ties with Central Asia could help diversify the energy export routes and break the possible Russian and Chinese monopoly over these energy resources that the U.S. feared, and its democratic political system could also serve as a model for Central Asian states. Pakistan, as an important stakeholder and a key player in Afghanistan's reconstruction, is indispensable for any prospect of a coalition victory in the Afghan war. In addition, by promoting trade and the construction of transport infrastructure, the U.S. aimed to rebuild Afghanistan with a view to maintaining long-term stability and security in Afghanistan. ${ }^{27}$

\section{The EU Approach: A New EU-Central Asia Partnership}

Central Asia is a region where the EU has substantial interests at stake and has become deeply involved since the end of the Cold War. First of all, the EU's strategic interests in Central Asia are primarily in ensuring security and stability. ${ }^{28}$ This is mainly because Central Asia now borders with the target states involved in the European Neighborhood Policy and the Black Sea Synergy Initiative; as a result, various kinds of instabil-

23 Atajan Iazmuradov, "Greater South Asia - America's New Regional Approach to Central and South Asia: How It is Developing and What Prompted It," Central Asia and the Caucasus 4:40 (2006): 80; available at www.ca-c.org/journal/2006-04-eng/09.pr..iazmuradoven.shtml.

24 This project was led by the Central Asia-Caucasus Institute of the Paul H. Nitze School of Advanced International Studies at Johns Hopkins University in 2005.

25 Ambassador Richard Boucher, "Pursuing Peace, Freedom and Prosperity in South and Central Asia," remarks before the Senate Foreign Relations Committee (Washington D.C., 16 February 2006); available at www.state.gov/p/sca/rls/rm/2006/61317/htm.

26 The National Security Strategy of the United States of America (Washington, D.C.: The White House, March 2006), 39.

27 S. Frederick Starr, "A 'Greater Central Asia Partnership' for Afghanistan and Its Neighbors," 16.

28 Council of the European Union General Secretariat, European Union and Central Asia: Strategy for a New Partnership (Brussels: European Communities, October 2007): 8. 
ity and threats such as terrorism, drug-trafficking, and organized crime in the region could have a serious impact on the EU's security. ${ }^{29}$ Second, as Afghanistan's neighbors, three Central Asian states could provide crucial support for the EU member states operating in the ongoing Afghan war. Third, Central Asia could serve as an ideal alternative energy supplier for the EU, which would decrease its dependence on Russian energy resources.

Although nowadays it is quite clear that it "has a strong interest in a peaceful, democratic, and economically prosperous Central Asia," ${ }^{30}$ the EU initially did not seem to realize the strategic importance of this region, and thus did not put forward a comprehensive approach in the 1990s. However, as the biggest donor to nations in Central Asia, it did involve the region in some projects focusing on "economic and technical questions" 31 - e.g., Technical Assistance to the Commonwealth of Independent States (TACIS), the Transport Corridor Europe-Caucasus-Asia (TRACECA), and the Partnership and Cooperation Agreements (PCAs) ${ }^{32}$ - which to some extent promoted the Central Asian states' economic and social development. After 11 September 2001, the EU adopted more security-focused projects in the region, such as the Central Asia Drug Program (CADAP) and Border Management in Central Asia (BOMCA) aimed at adapting to the new security situation there.

In 2007, with the publication of the document "European Union and Central Asia: Strategy for a New Partnership," the EU adopted a "comprehensive and long-vision approach" toward Central Asia. ${ }^{33}$ Under this new strategy, the EU will establish a variety of cooperation mechanisms, namely "a regular regional political dialogue at [the] Foreign Minister level," the European Education Initiative, the "e-silk-highway," the EU Rule of Law Initiative, a formalized human rights dialogue, and an energy dialogue with the Central Asian states.

There is also an emphasis on bilateral cooperation in the EU's overall approach to Central Asia. In the areas of human rights, economic development, and education, cooperation will be conducted on a bilateral basis, considering the different conditions in each regional state. And, according to the EC 2007-2013 Regional Assistance Strategy for Central Asia (another important document elaborating the EU's approach to the region), 70 percent of a fund of EUR 750 million for assistance for Central Asia will be allocated to bilateral projects. ${ }^{34}$ In addition, the EU will also conduct dialogues with

Ibid., 8.

${ }^{31}$ Nicolas de Pedro, "The EU in Central Asia: Incentives and Constraints for Greater Engagement," in Great Powers and Regional Integration in Central Asia: A Local Perspective, eds. Mario Esteban and Nicolas de Pedro (Madrid: Exlibris Ediciones S.L., 2009), 116.

32

bid., 116.

33 Ibid., 117.

${ }^{34}$ European Union, "European Union and Central Asia: Strategy for a New Partnership," 28. 
other regional organizations involved in Central Asia, such as the UN, the OSCE, EURASEC, the SCO, and the CSTO. ${ }^{35}$

\section{China's Approach: SCO}

China, "as the most powerful, dynamic, and immediate neighbor of Central Asia," has vital strategic, security, and economic interests in the region. First and foremost, ensuring overall stability in the region - and especially tranquility on its borders - will help create a favorable regional environment for China's internal economic development, and thus facilitate its future rise to global power status. In the meantime, creating a friendly neighborhood and "a harmonious region of lasting peace and common prosperity" ${ }^{37}$ that could accommodate China's growing influence is also strategically essential. Second, it is in China's interests to cooperate with its Central Asian neighbors in addressing some immediate security concerns it faces, like combating separatism in Xinjiang Province, as well as cross-border drug trafficking and organized crime in a regional context. Third, in terms of economic interests, Central Asia also represents both a rich energy source for Chinese industry and a huge market for Chinese goods.

China's approach to regionalism in Central Asia mainly takes place within the framework of the Shanghai Cooperation Organization (SCO). The SCO's predecessor, the "Shanghai Five," was originally set up in 1996 as a mechanism aimed at solving border issues and building confidence between China and Russia as well as China's other three Central Asian neighbors. Based on the successes achieved through this process, the SCO was formally established in 2001, and since then its development has gained tremendous momentum. The level and range of cooperation within the SCO has expanded from the security area to a variety of other areas such as trade, energy, education, cultural communication, and tourism. ${ }^{38}$ This might serve to increase the level of interdependence between regional states and "consolidate the social basis of the SCO." 39

Security cooperation has always been high on the SCO's agenda. Faced with the common threats of terrorism, separatism, and extremism, along with the prevalence of cross-border criminal networks, SCO member states have held several common military exercises and agreed on improving information sharing and coordination between

35 Ibid., 11; see also Diana Golikova, "Central Asia Seminars - $2^{\text {nd }}$ GCSP-NUPI-OSCE Academy Seminar, 'Central Asia 2009,’” GCSP Geneva Paper 13 (2010), 10.

36 Zbigniew Brzezinski, Foreword, in Bates Gill and Matthew Oresman, "China's New Journey to the West: China's Emergence in Central Asia and Implications for U.S. Interests," a Report of the CSIS Freeman Chair in China Studies (August 2003).

37 Alyson J.K. Bailes, et al., The Shanghai Cooperation Organization, SIPRI Policy Paper No. 17 (Stockholm: SIPRI, 2007): 48.

38 SCO website: www.sectsco.org/html/00026.html.

39 Hu Jintao, speech at the sixth SCO Summit, Shanghai (15 June 2006); available from the website of the Foreign Ministry of China, at www.fmprc.gov.cn/chn/pds/wjb/zzjg/dozys/ dqzzoys/shhz/xgxw/t258248.htm. 
them. Combating common security threats, therefore, is an important motivating factor for the development of the SCO.

China in particular has also viewed effective economic cooperation as a key driving force for building regionalism in Central Asia. Its proposal to establish a free trade zone within the SCO framework is a direct attempt to build closer economic ties between the states. China also established a USD 900 million fund to promote economic development in the Central Asian states. The construction of regional infrastructure projects - for example, the cross-border railway network - and the establishment of an "energy club" would further deepen the economic linkages between states in the region. Through its promotion of regional economic cooperation, China has gained mounting influence in the SCO and in the region due to its strong economic power.

In addition, China has also made efforts to promote the institutionalization of the $\mathrm{SCO}$ as an effective way to strengthen regionalism in Central Asia. ${ }^{40}$ The SCO Secretariat and its Regional Anti-Terrorist Structure (RATS) were set up in 2004. Some NGOs were also established within the SCO framework; for example, the Business Council, the Inter-bank Consortium, and the SCO Forum were all created in order to facilitate cooperation among member states.

It should be noted that the SCO shows to some extent an open attitude in cooperating with other states, organizations, and regions. By bringing in Mongolia, India, Pakistan, and Iran as observers, as well as Belarus and Sri Lanka as dialogue partners, the $\mathrm{SCO}$ has worked to bolster its influence in other parts of Asia. An Afghanistan Contact Group was established in order to contribute to improving Afghanistan's situation. Moreover, the SCO has been maintaining dialogue with the UN, the EU, the OSCE, the CSTO, the CIS, EURASEC, and ASEAN.

\section{Russia's Approach: CSTO, EURASEC, and SCO}

Due to its geographic proximity to Central Asia, Russia has a variety of interests there. Politically, one key interest of Russia lies in the "the preservation of the internal stability of the Central Asian nations," since any kind of instability in its backyard could spill over and threaten its own security. ${ }^{41}$ Economically, Russia's oil and gas exports to Europe as well as its energy-driven economic growth would be seriously affected if it could not have stable access to energy resources in Central Asia. ${ }^{42}$ In terms of security, Russia is faced with threats like terrorism, extremism, and drug trafficking filtering across its "vulnerable southern borders." ${ }^{43}$ Strategically, it is in Russia's interests to

40 Bailes, et al., The Shanghai Cooperation Organization, 49.

41 Igor Torbakov, "From Hegemony to New Geopolitical Competition: Assessing Russia's Strategic Footprint in Central Asia," Finnish Institute of International Affairs Briefing Paper 22:6 (October 2008): 3; available at www.ciaonet.org/pbei/fiia/0008193/index.html.

42 Nikolay Kuzmin, "Central Asia: The Sphere of Russia's Privileged Interests," in Great Powers and Regional Integration in Central Asia: A Local Perspective, ed. Mario Esteban and Nicolas de Pedro (Madrid: Exlibris Ediciones S.L., 2009), 16.

43 Richard Weitz, "Averting a New Great Game in Central Asia," The Washington Quarterly 29:3 (Summer 2006): 156. 
maintain its dominant influence in Central Asia while properly dealing with the competition from other major powers like the U.S., China, and the EU. ${ }^{44}$

Given Russia's long-standing dominant role in the region, the Central Asian states have long been drawn into its overall design of multilateral networks and become member states of the CIS, the CSTO, EURASEC, and the SCO. However, since the CIS is already in the process of a "slow death," driven by its lack of substantial achievement and the turn of some member states toward the West, ${ }^{45}$ the CSTO, EURASEC, and SCO are the three key organizations that Russia relies on in its approach to regionalism in Central Asia.

The CSTO was established in 2003 on the basis of the Collective Security Treaty (CST) with Russia and six other former Soviet republics (Kazakhstan, Kyrgyzstan, Tajikistan, Uzbekistan, Belarus, and Armenia) as its members. As a "real defense alliance," ${ }^{46}$ CSTO members are obliged to assist each other with necessary means (military means included) in cases of aggression against any member state. So far, a variety of internal structures have been set up within the CSTO to facilitate member states' coordination in their joint efforts to combat terrorism, drug trafficking, and other security threats. To maintain its dominant role in the organization, Russia successfully proposed the building of a Collective Rapid Deployment Force as the main provider of both funding and personnel. In addition, Russia has also successfully maintained military bases in some member states, and even opened some new ones. In the wake of a few moderately successful military operations conducted within the CSTO framework, Russia has consolidated its preponderant influence in Central Asian security. And the CSTO, therefore, is regarded as the "basis for an effort at competitive regionalism," which is seen as a counterbalance against NATO's PfP. ${ }^{47}$

Economically, Russia uses EURASEC as the main framework to involve itself in regional economic cooperation in Central Asia. Against the backdrop of China's growing economic presence in the region, and in order to maintain its own economic influence, Russia provided strong support for the development of EURASEC. Since its founding in 2001, and especially after its merger with CACO in 2005, EURASEC has made achievements in promoting regional economic cooperation. It has established a free-trade zone between member states, which laid a firm foundation for the further development of regionalism in Central Asia. Efforts have also been made to form a customs union; by July 2010, Russia, Belarus, and Kazakhstan hope to launch their

44 Kuzmin, "Central Asia: The Sphere of Russia's Privileged Interests," 15.

45 Stephen Aris, "Russia's Approach to Multilateral Cooperation in the Post-Soviet Space: CSTO, EURASEC, and SCO," Russian Analytical Digest 76 (15 April 2010): 2, available at http://e-collection.ethbib.ethz.ch/view/eth:1620.

46 Ingmar Oldberg, "The Shanghai Cooperation Organization: Powerhouse or Paper Tiger?" FOI Paper (June 2007): 28, available at http://www2.foi.se/rapp/foir2301.pdf.

47 Roy Allison, "Regionalism, Regional Structures and Security Management in Central Asia," International Affairs 80:3 (2004): 471. 
customs union within EURASEC as an early step toward a large-scale union. ${ }^{48}$ And in 2009, member states arrived at a consensus to build a Joint Anti-Financial Crisis Fund to diminish the impact of the global financial crisis, to which Russia made the largest contribution. ${ }^{49}$

As an influential member of the SCO, Russia has also been deeply involved in its development. Through the SCO framework, it can not only forge closer relations with its Central Asian neighbors, but also further strengthen its strategic partnership with China. More importantly, the SCO provides an effective platform for Russia to counter the U.S.'s influence by calling on the U.S. to withdraw from the region. Therefore, Russia has been actively participating in both economic and security cooperation actions within the SCO framework.

It should be noticed that the Russian government has encouraged more robust interaction between CSTO and EURASEC in order to promote regional integration. ${ }^{50} \mathrm{How}-$ ever, although it is a dominant member in the SCO, Russia has also been trying to blunt the SCO's influence in economic and security cooperation efforts in the region. For example, Russia rejected China's proposal on the creation of a free-trade zone within the SCO framework; as a result, the SCO will likely fall behind EURASEC in the area of economic cooperation. Meanwhile, Russia tried hard to pull the CSTO-a more organized and integrated military organization - into the joint exercises among SCO members, so that the SCO would not be given full play in regional security cooperation. In this way, Russia not only contains China's rising role in the region but also guarantees the CSTO and EURASEC decisive roles in these two areas.

\section{Comparison and Evaluation: Which is the Best Approach to Regionalism in Central Asia?}

The approaches of the great powers to regionalism in Central Asia described in the previous section each have their own strengths and weaknesses, reflected in the interests they serve, the policy instruments they adopt, and the effects they produce. The proper model for an approach to regionalism, therefore, should be that with the greatest convergence of strengths and the smallest number of weaknesses. This section will attempt to arrive at an identification of an optimal model through a comparison of the various approaches.

\section{Strengths and Weaknesses of the Approaches}

Comparison of Interests. There is no doubt that each of the major powers discussed in this essay became involved in Central Asia primarily due to their own interests. Therefore, how much they will contribute to the development of regionalism there largely

48 Stephen Aris, "Russia's Approach to Multilateral Cooperation in the Post-Soviet Space: CSTO, EURASEC, and SCO,” 3.

49 Ibid., 3.

50 Ikboljon Qoraboyev, "A Move away from Geopolitics in Central Asia: A Call for a Move to Institutions," paper submitted to the Garnet Sixth Ph.D. School at the Institute for European Studies, Brussels (June 2008); available at www.garnet-eu.org/Sixth_PhD_School.320.0.html. 
depends on the extent to which their own interests converge with that of the region in terms of regional integration. Moreover, whether a great power is seeking to pursue short-term concrete interests or long-term strategic interests in Central Asia is also a factor affecting the development of regionalism.

For the EU and China, maintaining lasting security and stability through integration is in their long-term interests. Their interests in diversifying the energy transport routes in Central Asia also coincide with those of the local states. In this sense, the EU and China basically share common interests with the regional states in promoting the integration process.

Russia's interest in maintaining its dominant presence in Central Asia and keeping order in a region that is an important strategic neighbor converges with that of the regional states in terms of regional cooperation, because only a region that is integrated in the areas of economy and security could serve as an ideal backyard in strategic terms. But, on the other hand, its dominance in the region is also regarded as an obstacle that could impede the spontaneous regionalization of Central Asia.

As for the U.S., its primary interest in Central Asia lies in supporting and winning the Afghan war. This to some extent coincides with the interests of the Central Asian states, since the development of economic, political, and security cooperation in the regional context requires a stable and secure regional environment. But the United States' interest is not directly linked with the promotion of regional cooperation, and contributes little to regional institution building. Besides, the U.S. focus on the Afghan war also reflects the pursuit of short-term concrete interests without considering longterm issues of regional economic and political development. ${ }^{51}$ As mentioned above, another key U.S. strategic interest in the region is to contain the growing influence of Russia, China, and Iran. This in some way runs counter to the interests of Central Asian states, because under the circumstances of great power competition, they will likely have to take sides, which could easily hinder the development of regionalism.

Comparison of Policy Instruments. A comparison of the policy instruments the great powers have applied in their approaches to regionalism in Central Asia could be conducted in three dimensions. The first dimension compares bilateralism versus multilateralism. Interestingly, although multilateralism is regarded as the essential way to develop regionalism, all of the major powers have adopted bilateralism as a key principle in their respective approaches to Central Asia. The U.S. to a large extent relies on bilateral relations with the Central Asian states to pursue its interests, and "has displayed little sustained interest in regional cooperation in Central Asia." ${ }^{52}$ In comparison, Russia and China have devoted themselves to multilaterally promoting regional cooperation in Central Asia, although bilateral cooperation is still a significant element of their multilateral cooperation frameworks. Especially in the SCO, due to its inefficient decision-making structure and weak capabilities for collective behavior, both Russia and China widely work on bilateral cooperation projects with other SCO mem-

51 Macfarlane, "The United States and Regionalism in Central Asia," 456.
52 Ibid., 457. 
ber states. In the case of the EU, due to its unsuccessful previous experience in promoting multilateral cooperation with Central Asia, the strategy of building a new partnership includes both bilateral and multilateral approaches, with an emphasis on the former.

The second comparative dimension involves evaluating a comprehensive approach versus a partial approach. The EU's creation of a new partnership with Central Asia represents a comprehensive approach to promoting regional cooperation that covers economic, political, social, and energy aspects. In comparison, Russia's approach mainly focuses on economic and security issues, while the U.S. emphasizes military and economic cooperation within the Greater Central Asian area. The SCO's agenda has been rapidly expanded since its establishment, from focusing merely on issues of economy and security to a variety of other areas like education, cultural exchange, science, technology, and environmental protection. ${ }^{53}$ It should be admitted, however, that no substantial progress has been made so far in these newly added areas.

The third comparative dimension is that of "soft regionalism" versus "hard regionalism." "Soft regionalism" refers to the promotion of "a sense of regional awareness or community through consolidating regional groups and networks," while "hard regionalism" means the building of "pan- or sub-regional groups formalized by interstate arrangements and organizations." 54 In this regard, China has adopted the "hard regionalism" approach by establishing regional organizations and their relevant mechanisms. The U.S. has also engaged in building interstate arrangements in the area of security cooperation, even though it did not set up any concrete regional structures. In contrast to these two powers, the EU did not only work with the regional governments to promote some interstate projects, but also devoted attention to cultivating social networks and positive social developments through a variety of education cooperation initiatives aimed at the formation of a regional identity. Russia too has worked on both tracks. Alongside efforts to establish formal regional organizations, it also makes use of its soft power (such as the influence of the Russian language) as a way to maintain regional awareness in Central Asia. ${ }^{55}$

Comparison of Effects. The various approaches of the great powers to regionalism in Central Asia have produced complex effects, which in turn have revealed the difficulties caused by the complicated geopolitical competition in the region. Specifically, these effects can be examined from three aspects: regional cooperation, regional states, and the great powers.

First, it should be noted that with the establishment of regional organizations and their relevant institutions by the great powers, the processes of regional integration have been promoted both within individual organizations and across the arrangements. Nevertheless, the competition between the different approaches taken by the great

53 See www.sectsco.org/html/00026.html.

54 Fawcett, "Exploring Regional Domains: A Comparative History of Regionalism," 433.

55 Fiona Hill, "Russia's Newly Found 'Soft Power'," The Globalist (26 August 2004); available at www.theglobalist.com/StoryId.aspx?StoryId=4139. 
powers is also salient. For example, Russia tried hard to reject the formation of a freetrade zone within the SCO in order to ensure that EURASEC could play a larger role in regional economic cooperation. The U.S. has also sought to balance the dominant influence of the Russia-led regional organizations by pulling Central Asia into a larger trans-regional context. These forms of competition could easily help to counter the effects of regional integration, or even result in the "fragmentation" of Central Asia. ${ }^{56}$

Second, multiple efforts have been made by the regional states to either balance or align with external great powers, which could be harmful for long-term regional integration in Central Asia. Regional states chose to "bandwagon" the U.S. and Russia at the same time in order to maximize the economic and military gains to be accrued from both sides. They also use the U.S. and Russia to balance each other for their own benefit. Even within the SCO, Central Asian states use Russia or China to check each other so that they can minimize the chance of being manipulated by them. Moreover, due to the interstate disputes and distrust between Central Asian states, they also use large external powers as tools to gain more leverage and more favorable status with respect to each other. And finally, states like Uzbekistan, which has achieved most of its goals simply by cooperating bilaterally with the U.S., may lose interest in further regional cooperation. ${ }^{57}$ All these factors could impede the further promotion of regionalism in Central Asia.

Third, the competition between the great powers could become even more severe due to the development of regional institutions. For example, the SCO has always been viewed by the U.S. as a platform that could be used by Russia and China to challenge its strategic interests and seek to control energy resources in Central Asia. As a response, the U.S. has further increased its bilateral ties with regional states to ensure its strategic interests in the region. And this in turn has been perceived by Russia and China as part of the U.S. policy of strategic containment toward them. The Central Asian region, therefore, could come to be reinforced as a "testing ground for new great-power relations," and the development of regionalism there might be hindered further. ${ }^{58}$

\section{Evaluation: The EU Approach as the Proper Model?}

After a comprehensive comparison of the great powers' various approaches to regionalism in Central Asia, a conclusion could be drawn that theoretically the EU approach represents the proper model, ${ }^{59}$ since it is the one characterized by the largest convergence of strengths and a minimum of weaknesses.

56 Qoraboyev, "A Move away from Geopolitics in Central Asia."

57 Macfarlane, "The United States and Regionalism in Central Asia," 459.

58 See Geir Flikke and Julie Wilhelmsen, Central Asia: A Testing Ground for New GreatPower Relations (Oslo: NUPI, 2008).

59 Nicolas de Pedro, "The EU in Central Asia: Incentives and Constraints for Greater Engagement," in Great Powers and Regional Integration in Central Asia: A Local Perspective, eds. Mario Esteban and Nicolas de Pedro (Madrid: Exlibris Ediciones S.L., 2009), 130-132. 
As discussed above, the EU approach upholds the long-term interests of security and stability in Central Asia, which converge with those of the regional states. It adopts both bilateral and multilateral means to promote a comprehensive system of regional integration, including the cultivating of regional identity as the "soft" side of regionalism. And as the largest donor to the states in Central Asia, it has provided considerable tangible assistance to the region. In addition, the EU and its approach did not become deeply involved in the complex competition and balance between different parties, and thus overcame a key limitation of geopolitics in Central Asia, a success that "in itself serves to facilitate its access to the region." 60

Moreover, the EU approach also has other crucial advantages. First, the EU itself could serve as a perfect model for the development of regionalism. Its historical experiences in overcoming interstate disputes and building mutual trust between member states would be intrinsically valuable for Central Asian states. Second, with an emphasis on economic diversification and the promotion of education, the EU approach would be conducive to the economic and social development of Central Asian states which is an important condition for the development of regionalism. Third, with Kazakhstan as the chair of OSCE in 2010, now is the perfect time for the EU to promote its strategy of partnership with Central Asia and facilitate its cooperation with the regional states. ${ }^{61}$

However, the EU approach does have its own weaknesses. The lack of efforts in institution building could constrain the effectiveness of its approach to regionalism. The promotion of democracy and human rights within the framework of the EU-Central Asia Partnership could easily run counter to the regional states' emphasis on stability, and could consequently lead those states to reject the EU approach.

Although theoretically the EU approach represents the proper model, in practice its involvement in the promotion of regional cooperation in Central Asia has fallen substantially short of expectations. It is true that the EU's new partnership strategy has made achievements while being implemented in the past several years. For example, there have been more scholarship opportunities provided to Central Asian students, and new projects such as the Central Asia Invest program aimed at promoting the economic development of the Central Asian states have been established. But, compared with the other great powers, the EU's involvement has been relatively insignificant. The reason behind this is apparently the EU's lack of incentives and interests in this region due to its limited economic and social ties with the Central Asian states. However, with the common economic and security challenges facing both the EU and Central Asia increasing, the EU-in its role as a normative and economic power-should devote more attention to the region. On the one hand, the EU should allocate more resources to support economic and social development in the region, and thus cultivate deeper ties with the regional states. On the other hand, the existing mechanisms aimed at promoting regional cooperation should be fully made use of within the framework of

60 Ibid., 132.
61 Ibid., 131. 
the new partnership strategy. And finally, the EU should be very cautious and skillful when it seeks to promote the cause of human rights and democracy there. In sum, the EU approach is the proper model to regionalism in Central Asia, possessing a number of strengths. But it also faces several internal weaknesses that could undermine its efforts in promoting regional integration.

\section{Conclusion}

Because of its geostrategic importance and rich energy resources, Central Asia has become a new test case for great-power relations since the end of the Cold War, and especially since 11 September 2001. Due to the failure of CACO (a spontaneously initiated Central Asian regional institution), the development of regionalism in Central Asia now primarily lies in the hands of large external powers, namely, Russia, China, the EU, and the US. They have adopted various approaches to promoting regional integration in Central Asia, which to some extent has facilitated regional cooperation. But the competition between the different approaches has also hindered the progress of regionalism. After a comprehensive comparison of the various approaches to regionalism in Central Asia, a conclusion could be drawn that the EU approach represents the proper model. As a comprehensive approach, it is not only conducive to the overall economic and social development of the regional states; it could also overcome the limitations of geopolitics in Central Asia. Under the new strategy of EU-Central Asia partnership, the EU will contribute to the enhancement of regionalism in the region. 


\section{Bibliography}

Allison, Roy. "Regionalism, Regional Structures and Security Management in Central Asia." International Affairs 80, no. 3 (2004): 464.

Aris, Stephen. "Russia's Approach to Multilateral Cooperation in the Post-Soviet Space: CSTO, EURASEC, and SCO." Russian Analytical Digest 76 (2010): 2.

Bailes, Alyson J. K.. The Shanghai Cooperation Organization In Policy Paper. Stockholm: SIPRI, 2007.

Blank, Stephen. "The Strategic Importance of Central Asia." Parameters (2008): 73.

Bohr, Annette. "Regionalism in Central Asia: New Geopolitics, Old Regional Order." International Affairs 80, no. 3 (2004): 485.

Brzezinski, Zbigniew, in Bates Gill Foreword, and Matthew Oresman. China's New Journey to the West: China's Emergence in Central Asia and Implications for U.S. Interests. CSIS Freeman Chair in China Studies, 2003.

Cornell, Svante E.. "The United States and Central Asia: in the Steppes to Stay?" Cambridge Review of International Affairs 17, no. 2 (2004): 242.

de Pedro, Nicolas. "The EU in Central Asia: Incentives and Constraints for Greater Engagement." In Great Powers and Regional Integration in Central Asia: A Local Perspective, 116. Madrid: Exlibris Ediciones S.L., 2009.

Esteban, Mario, and Nicolas de Pedro. Great Powers and Regional Integration in Central Asia: A Local Perspective. Madrid: Exlibris Ediciones S.L., 2009.

European Union and Central Asia: Strategy for a New Partnership. Brussels: European Communities, Council of the European Union General Secretariat, 2007.

Fawcett, Louise. "Exploring Regional Domains: A Comparative History of Regionalism." International Affairs 80, no. 3 (2004): 433.

Flikke, Geir, and Julie Wilhelmsen. Central Asia: A Testing Ground for New GreatPower Relations. Oslo: NUPI, 2008.

Hill, Fiona. "Russia's Newly Found 'Soft Power'." The Globalist (2004).

Iazmuradov, Atajan. "Greater South Asia - America's New Regional Approach to Central and South Asia: How It is Developing and What Prompted It." Central Asia and the Caucasus 4, no. 40 (2006): 80.

Jintao, Hu. Hu Jintao, speech at the sixth SCO Summit. Shanghai: the web-site of the Foreign Ministry of China, 2006.

Kuzmin, Nikolay. "Central Asia: The Sphere of Russia's Privileged Interests." In Great Powers and Regional Integration in Central Asia: A Local Perspective, 16. Madrid: Exlibris Ediciones S.L., 2009. 
McKeown, Timothy. "Hegemonic Stability Theory and Nineteenth-Century Tariff Levels in Europe." International Organization 37, no. 1 (1983): 73-91.

Mittelman, James H., and Richard Falk. "Hegemony: The Relevance of Regionalism?" In National Perspectives on New Regionalism in the North, 175. London: Macmillan, 1999.

Oldberg, Ingmar. The Shanghai Cooperation Organization: Powerhouse or Paper Tiger?. FOI Paper, 2007.

Qoraboyev, Ikboljon. A Move away from Geopolitics in Central Asia: A Call for a Move to Institutions. Vol. 80. Brussels: Garnet Sixth Ph.D. School at the Institute for European Studies, 2008.

Rumley, Dennis. "The Geopolitics of Asia-Pacific Regionalism in the 21st Century." The Otemon Journal of Australian Studies 31 (2005): 9.

S. Macfarlane, Neil. "The United States and Regionalism in Central Asia." International Affairs 80, no. 3 (2004): 447.

S. Starr, Frederick. A 'Greater Central Asia Partnership' for Afghanistan and its Neighbors In Silk Road Paper. Central Asia-Caucasus Institute, Silk Road Studies Program, 2005.

The National Security Strategy of the United States of America., 2002.

Torbakov, Igor. "From Hegemony to New Geopolitical Competition: Assessing Russia's Strategic Footprint in Central Asia." Finnish Institute of International Affairs Briefing Paper 22, no. 6 (2008): 3.

Weitz, Richard. "Averting a New Great Game in Central Asia." The Washington Quarterly 29, no. 3 (2006): 156. 